\title{
日本海沿岸における台風通過後の異常高潮の 発生メカニズムに関するー考察

\author{
Mechanism of Abnormal Storm Surges after Passage of Typhoons \\ around West Coasts of the Sea of Japan
}

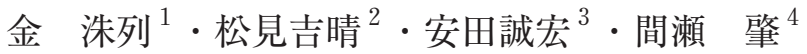

\author{
Soo Youl KIM, Yoshiharu MATSUMI, Tomohiro YASUDA and Hajime MASE
}

\begin{abstract}
The present study discusses the mechanism of abnormal storm surges occurred at Sakai-Minato located west coasts of the Sea of Japan due to Typhoon Songda. The storm surge simulations by SuWAT (Surge-Wave-Tide coupled model) are conducted with and without Coriolis forces and river discharges as well as using different calculation regions. The analysis indicated that the Coriolis force is a predominant factor for the abnormal storm surge with time lags of 15 hours at the coastal regions in the Sea of Japan if the meteorological forcing is correct. The maximum contribution of the Coriolis force to the peak storm surge is $70 \%$. The influence of the river discharge is insignificant. For the storm surges generated in the Pacific Ocean, the effect of the Coriolis force is insignificant as about $1 \%$ for the Typhoon Anitaf's storm surge.
\end{abstract}

\section{1. はじめに}

高潮発生の主な要因は, 風による吹き寄せと気圧低下 による吸い上げである。また，最近の研究によると波に よる wave setupの影響も重要であることがわかっている (柴木ら，2001; 金ら，2008). その他に, 運動方程式に 含まれているCoriolis力項の影響も重要であるが，高潮 に及ぼす影響に関する研究は少ない。

日本海沿岸に位置する境港における高潮は，台風最接 近時に最大になるのではなく，台風通過後の西風または 北西風により島根県沿岸に生じた水位上昇が東方に伝わ り, 台風通過の十数時間後に最大の高潮偏差が現れるこ とが示された（金ら，2009）。しかし，このような異常 高潮の発生メカニズムの原因は明らかにされていない.

本研究は, この境港における異常高潮を発生させる原 因として, Coriolis力と中海からの河川流量に注目して, 高潮シミュレーションにより，それらの影響を検討する ものである。また, 太平洋沿岸に位置する高知湾に対し てもCoriolis 力の有無による高潮計算を実施し, 境港で の結果と比較しながら Coriolis力の影響を調べる.

\section{2. 解析に用いた数值モデルおよび気象場の概要}

\section{（1）潮汐・高潮・波浪結合モデル}

本研究では, Kimら（2008，2010）による潮汐・高

\begin{tabular}{llll}
\hline 1 & 正会員 & 博(工) & $\begin{array}{l}\text { 鳥取大学大学院助教 } \\
\text { 工学研究科社会基 }\end{array}$ \\
2 正会員 & 工博 & $\begin{array}{l}\text { 鳥取大学大学院教授 } \\
\text { 工学研究科社会基 }\end{array}$ \\
3 正会員 & 博(工) & $\begin{array}{l}\text { 京都大学助教 } \\
4\end{array}$ 防災研究所 \\
正会貝 & 工博 & 京都大学教授 & 防災研究所
\end{tabular}

潮・波浪の相互作用を考慮した双方向結合モデル SuWATを用いた。この計算モデルは，潮汐計算モジュ ール，高潮計算モジュールおよび波浪計算モジュールの， 3つの主要モジュールから構成されている. 高潮計算モ ジュールは非線形長波モデルを基礎式として用いてお り，波浪計算モジュールは第 3 世代波浪推算モデル SWANを用いている. 日本海では潮汐変動が小さいため, 本研究では潮汐計算は行わないこととした。

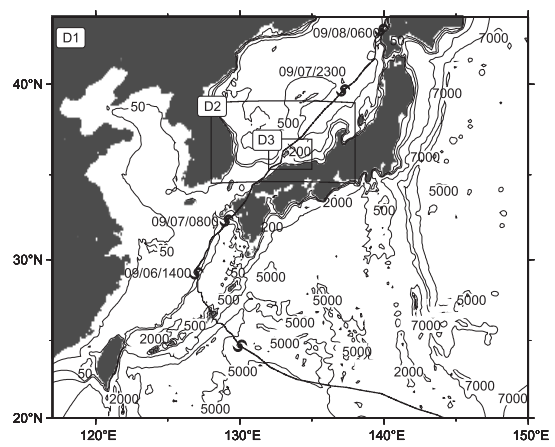

(a) D1 から D3 までの計算領域

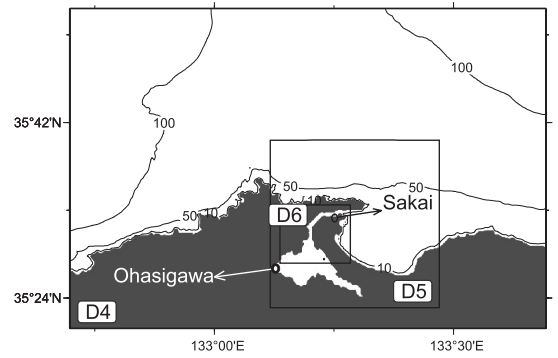

(b) D4 から D6 までの計算領域と河川境界の位置 (○)

図-1 6段階の計算領域とD5における河川境界の位置 


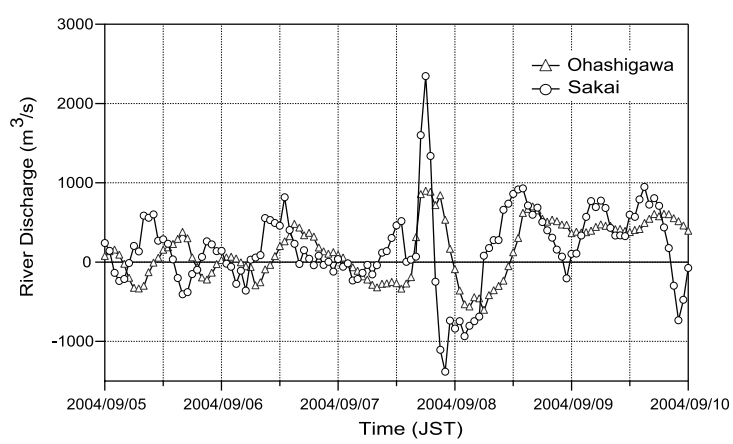

図-2 台風0418号来襲時の大橋川と境港での河川流量

\section{（2）気象場}

気象場の計算には，金ら（2008）で適用したメソ気象 モデルWRFを用いた。 WRFの入力デー夕には, 空間的 に 1 度毎, 時間的に 6 時間毎の NCEPの客観解析データ （FNL）を用い，WRFにより気象場をダウンスケーリン グした。 その解析結果を外力として, 順次SUWATに読 み达ませた. WRF計算での格子間隔は, 後述する高潮計 算格子間隔に合わせるため，第 1 領域では $12,150 \mathrm{~m}$ ，第 2 領域では 4,050m，第3領域では $1,350 \mathrm{~m}$ と設定した.

このダウンスケールされた気象場は，金ら（2008）に より先に行った観測值との比較から, 高潮計算の外力と して精度がよいことが確かめられている。

\section{（3）河川流量のための境界条件}

高潮計算に河川流量を考慮するためにFlather（1994） の境界条件を次のように適用した。

$$
\bar{U}_{n}=\bar{U}_{i} \pm \sqrt{g h}\left(\bar{\eta}_{i} \pm \bar{\eta}_{n}\right)
$$

ここで， $\bar{U}_{n}$ は境界における河川流量による流れ， $\bar{U}_{i}$ は計 算領域内での流れ, $g$ は重力加速度, $h$ は水深, $\bar{\eta}_{i}$ は計算 領域内での水位， $\bar{\eta}_{\eta}$ は河川流量による水位である.

河川流量による水位は

$$
\bar{\eta}_{n}=\frac{\Delta t}{\Delta x \Delta y} Q
$$

で求めた。ここで， $\Delta t$ は計算時間ステップ, $\Delta x$ および $\Delta y$ は $x$ と $y$ 方向の格子間隔, $Q$ は河川流量である. 図-1 (b) に大橋川と境水道から河川流量を流入させる位置を示し た.図-2は台風0418号の来襲時の各河川流量を示したも のである．高潮計算を行う前に河川流量を与えたspin up 計算を解が安定するまでに行った後, 気象場を与えて高 潮計算を行った。河川流量を与える計算領域は，格子間 隔が 2 番目に小さい第 5 計算領域D5のみとした $(150 \mathrm{~m})$.

\section{3. 解析結果}

\section{（1）Coriolis カの影響}

台風0418号に対して，図-1のD1～D6の6段階のネス ティング計算領域を用いて, 気圧低下，吹き寄せ，

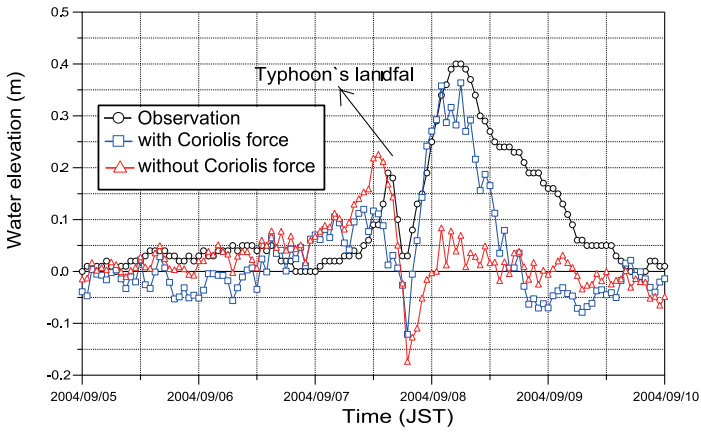

図-3 Coriolis力項の有無による高潮偏差の計算結果の比較

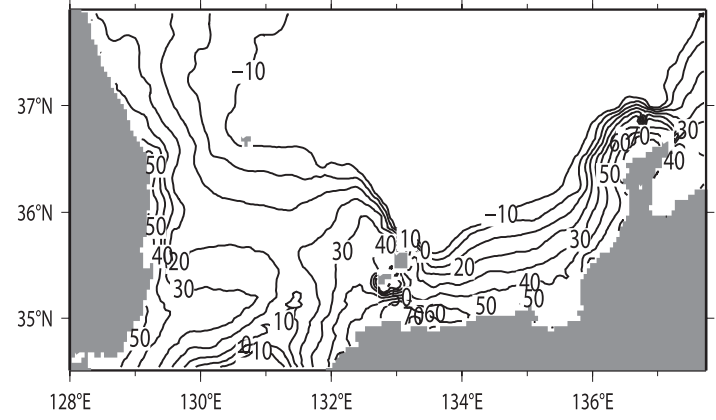

図-4 2004年9月 8 日 3 時における高潮に及ぼすCoriolis力の 影響 $(\%)$

Radiation Stress 考慮した条件の下に, Coriolis力項のあ る場合とない場合の高潮再現計算を行った。図-3は，境 港での Coriolis 力項の有無による高潮偏差を比較したも のである. Coriolis力がある場合は, 台風通過後の9月 8 日7時に最大高潮が発生していることを再現できている. しかし, Coriolis力がない場合には, 台風最接近時の水位 上昇を再現できるが，その後の最大高潮を再現できない. 図-4は，2004年9月 8 日 3 時における第2計算領域D2の, Coriolis 力のありとなしの高潮偏差の差と Coriolis力のあ りの高潮偏差の割合をパーセントで示してある. 従って, 高潮偏差に対するCoriolis力によって生じる高潮偏差の 割合である. 韓国東側, 山陰および能登半島沿岸域で 50 ７0\% 以上と, Coriolis力の寄与が大きいことがわかった. また，図-3に示した時系列の計算結果から，同時に起き た最大高潮偏差に及ぼす Coriolis 力の影響は，約 70\%で あることがわかった。

図-5および図-6は, Coriolis力項の有無による水位およ び風ベクトルの平面分布を示したものである。図-5 (a) と図-6 (a) の台風中心が接近した 2004年9月 7 日 17 時に は, Coriolis力項の考慮の有無に関わらず，水位上昇は同 じ傾向を示している. しかし, 台風中心が境港沿岸領域 を過ぎてからは異なる水位分布となる。すなわち，図-5 （b）に示す9月7日22時には, 山陰西側と能登半島沿岸 域で水位上昇が現れる. しかし, Coriolis力項がない場合 


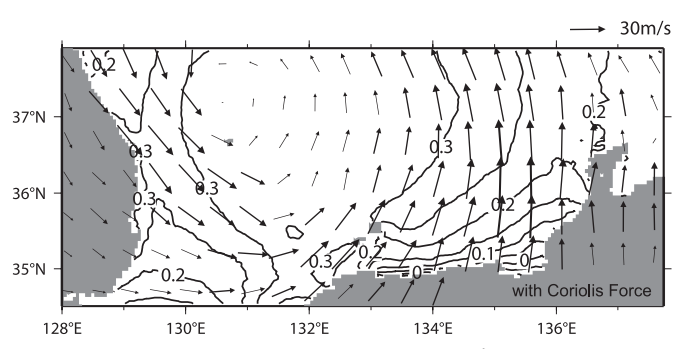

(a) 2004 年 9 月 7 日 17 時

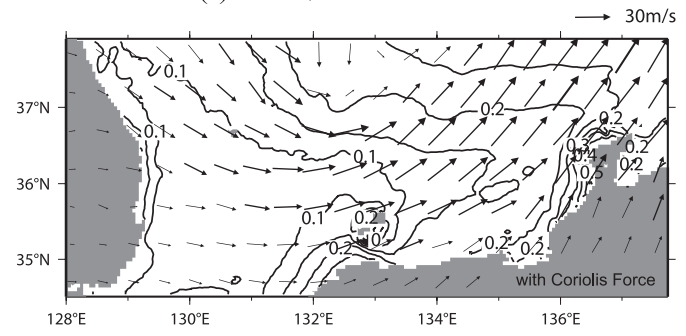

(b) 2004 年 9 月 7 日 22 時

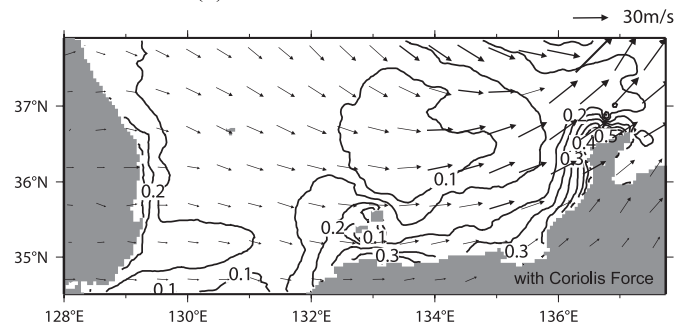

(c) 2004 年 9 月 8 日 2 時

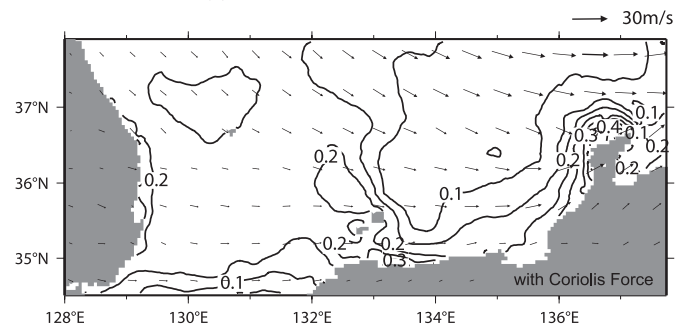

(d) 2004 年 9 月 8 日 8 時

図-5 Coriolis 力を考虑した場合の水位と風ベクトル

の図-6 (b) では，沿岸域での水位上昇がみられない。ま た，図-5 (c) と図-5 (d) にみられるように, Coriolis力の 効果により, 韓国東側, 山陰および能登半島沿岸域での 水位上昇とともに, 山陰および能登半島沿岸では水位が 西から東に伝わっている。しかし, Coriolis力がないと 図-6 (c) と図-6 (d) に示すように韓国東側, 山陰および 能登半島沿岸域で水位上昇が現れない.

図-7および図-8は, Coriolis力の有無による流れをそれ ぞれ示したものである. Coriolis力を考慮した場合, 図-7 （a）に示すように韓国東側では南向きの流れが発達して おり, 山陰と能登半島沿岸域では海岸線に平行な流れ場 が現れる。 その時の流速は, 沿岸域で最大 $100 \mathrm{~cm} / \mathrm{s}$ に達し ている. 図-7 (b) の9月 8 日2時には, 山陰と能登半島域

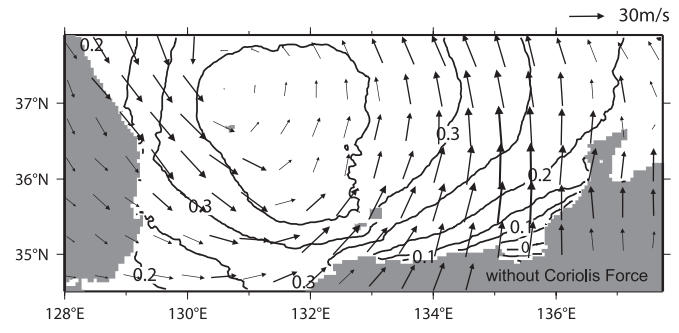

(a) 2004 年 9 月 7 日 17 時

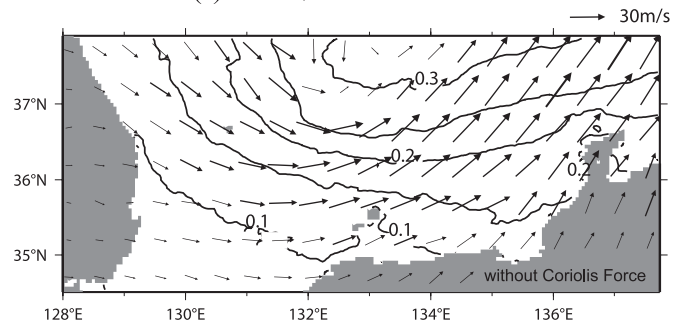

(b) 2004 年 9 月 7 日 22 時

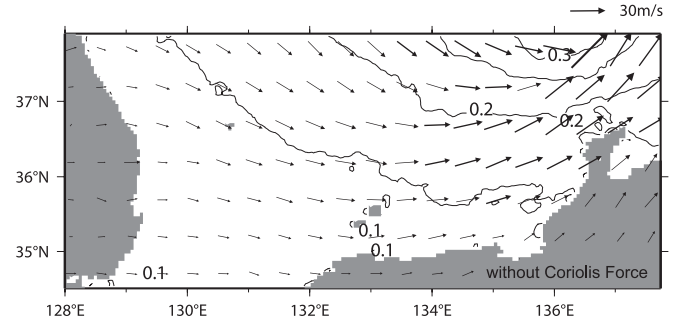

(c) 2004 年 9 月 8 日 2 時

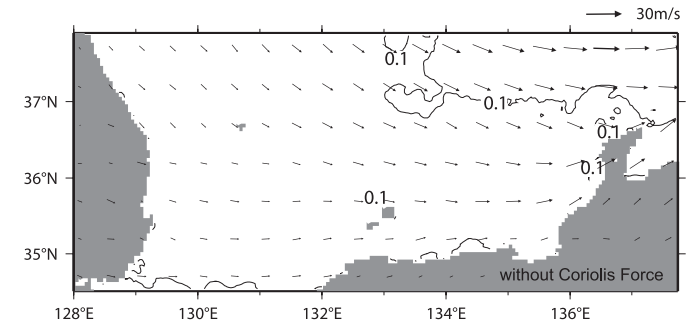

(d) 2004 年 9 月 8 日 8 時

図-6 Coriolis 力を無視した場合の水位と風ベクトル

における流れ場の向きは，(a) 図の向きょり右側に偏向 している，図-7 (c) の9月8日8時には，山陰沖合域では 南向きの流れが現れて, 沿岸域では東側に偏向している. 能登半島沿岸域では東南向きの流れが現れている. Coriolis力がない場合の図-8 (a)〜 (c) では, 流れが大きく なる領域ではCoriolis力を考慮した場合と同じ傾向がみら れたが，流れの向きは時間的にほとんど変わらなかった。

\section{（2）河川流量の影響}

河川流量の影響を調べるために，図-2に示した大橋川 と境水道の河川流量を用いて高潮計算を行った。図-9は, 境港における河川流量の有無による高潮偏差計算結果お よび河川流量のみによる潮位偏差を示したものである. 台風最接近時の 2004 年 9 月 7 日 18 時に境水道から最大流 


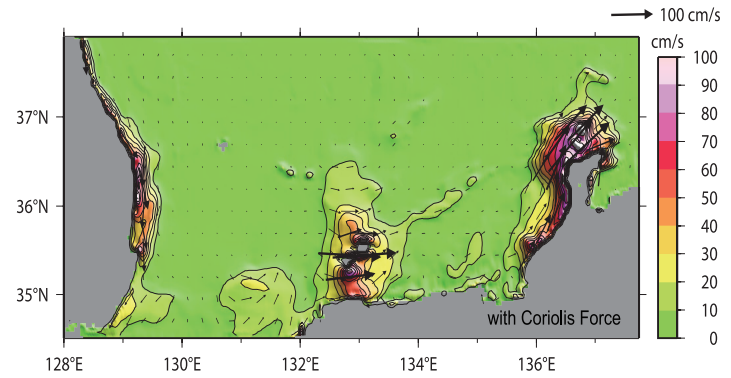

(a) 2004 年 9 月 7 日 22 時

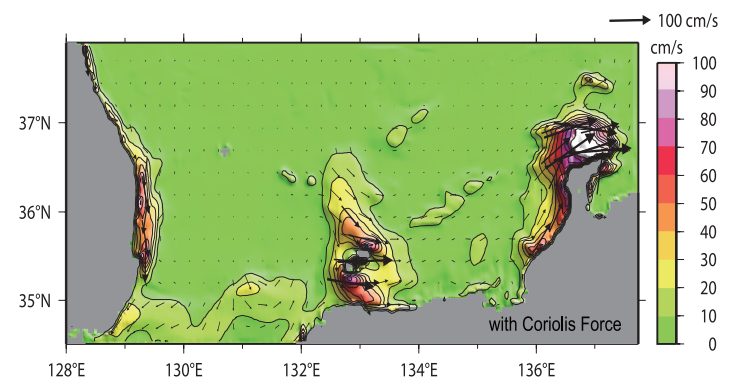

(b) 2004 年 9 月 8 日 2 時

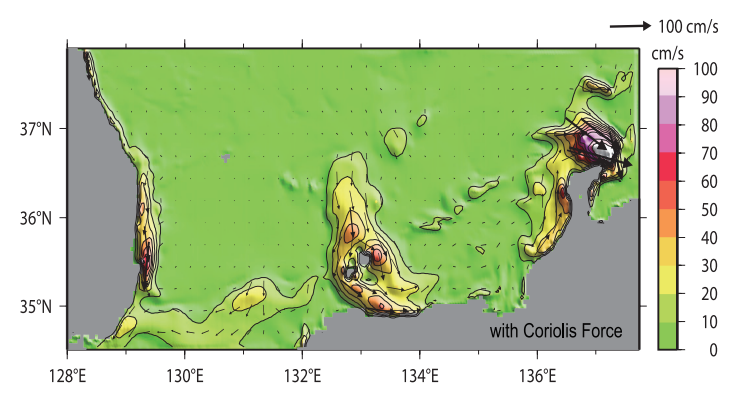

(c) 2004 年 9 月 8 日 8 時

図-7 Coriolis 力を考慮した場合の流れ

量が流入したため, 同時刻の河川流量を考慮した高潮偏

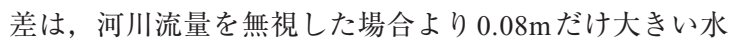
位上昇がみられたが, 最大高潮偏差の発生には河川流量 の影響は小さいといえる.

\section{（3）計算領域の影響}

図-1のように，D1～D6 （D1D6と呼ぶ）,D2〜D6 （D2D6） およびD3〜D6 （D3D6）の3つのネスティン グ領域の組み合わせを用いて, 高潮推算に及ぼす異なる 計算領域の影響について調べた。ここでは, 河川流量の 影響は無視した。D1D6の場合, 計算領域に太平洋, 日 本海および黄海が含まれており, 開境界は深海域に位置 している.D2D6の場合は，開境界は対馬海峡と日本海 の深海に位置する。D3D6では, 開境界は山陰沿岸沖に 位置する.

図-10は，境港における異なる計算領域による高潮偏

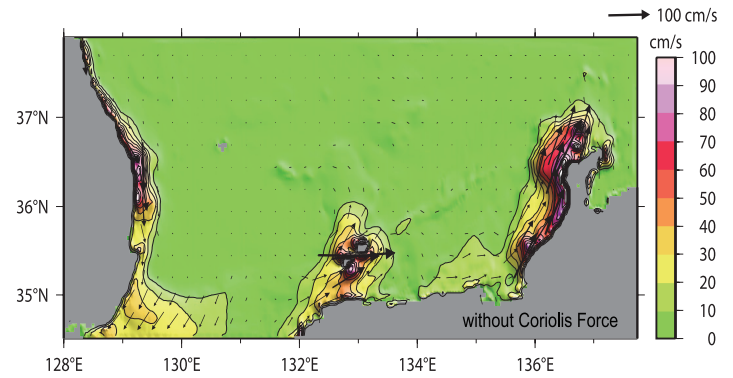

(a) 2004 年 9 月 7 日 22 時

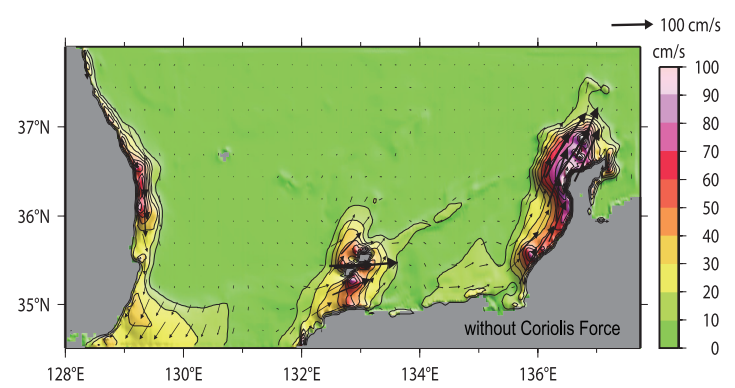

(b) 2004 年 9 月 8 日 2 時

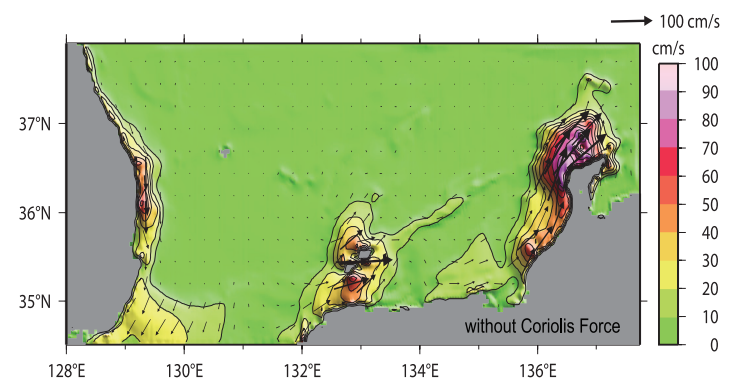

(c) 2004 年 9 月 8 日 2 時

図-8 Coriolis 力を無視した場合の流れ

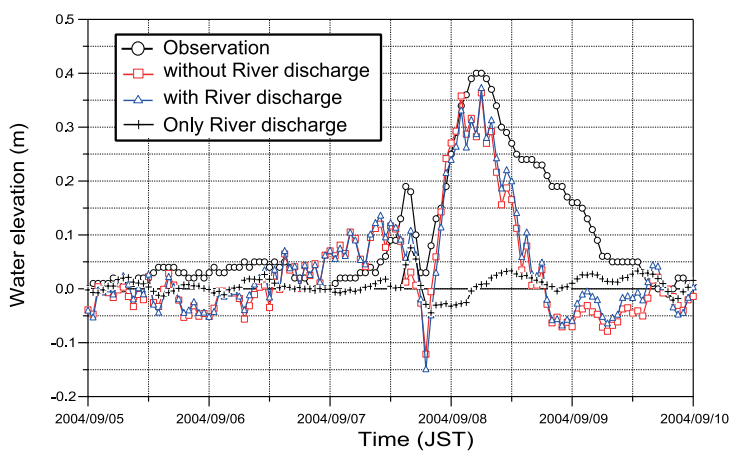

図-9 境港における河川流量の有無による高潮偏差計算結果 の比較

差の計算結果を比較したものである.D1D6とD2D6の場 合, 台風最接近時の水位上昇と低下が再現できるが D3D6の場合は, 計算された水位変動が観測結果と比べ て異なる. 台風通過後の最大高潮偏差は，3つの計算結 


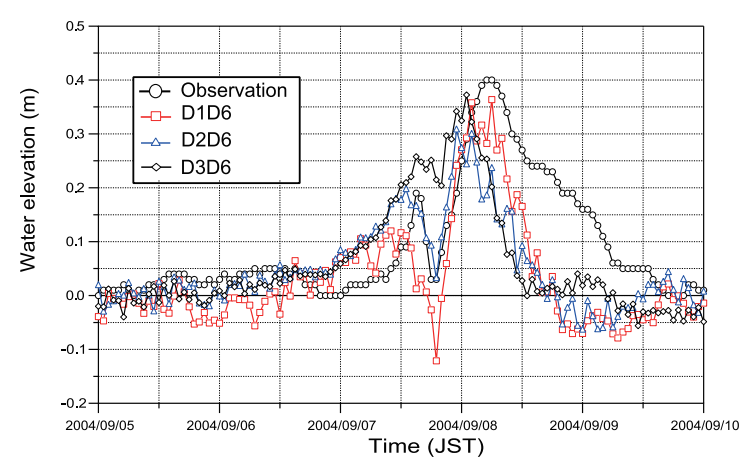

図-10 境港における異なる計算領域を用いた高潮偏差の計算 結果の比較

果のいずれでもみられるが，D2D6とD3D6の水位は D1D6のものより最大高潮偏差発生後に早く低下する. これは台風が山陰沿岸を通過後, 深海域での風により Coriolis力によって伝播してくる水位上昇を，D2D6と D3D6の計算領域では考慮できないためである。したが って, 日本海沿岸における高潮推算のためには, 日本海 全体を含む計算領域を用いる必要がある.

\section{（4）太平洋沿岸域の土佐湾での Coriolis 力の影響}

太平洋沿岸における高潮に及ぼす Coriolis力の影響を調 べるために，土佐湾に来襲した台風7010号を対象として， Coriolis力のある場合とない場合の高潮計算を行った.

図-11はKimら（2010）で対象にした7箇所における Coriolis力ありとなしとの差を示すとともに，手結におけ る高潮偏差を併記したものである．図のようにCoriolis 力による水位上昇は最大で約 $0.014 \mathrm{~m}$ を示した。この高潮 偏差に及ぼす影響は約 $1 \%$ 程度であった。日本海沿岸に おける高潮に及ぼすColiolis力の影響に比べて，太平洋沿 岸の土佐湾ではその影響は小さいことが分かった。

\section{5. おわりに}

本研究では, 日本海山陰沿岸の境港を対象に, SuWAT モデルを用いて, 台風 0418 号通過後に最大偏差が現れる 高潮の発生メカニズムの検討を行った。本研究で明らか になった主要な結果は, 以下のとおりである.

1）台風通過後に発生する最大高潮偏差に及ぼす Coriolis 力の影響は高潮偏差の約 $70 \%$ であった。 また，Coriolis 力は水位上昇だけではなく，流れ場にも影響を与える. 2）大橋川と境水道から流入する河川流量が, 台風通過

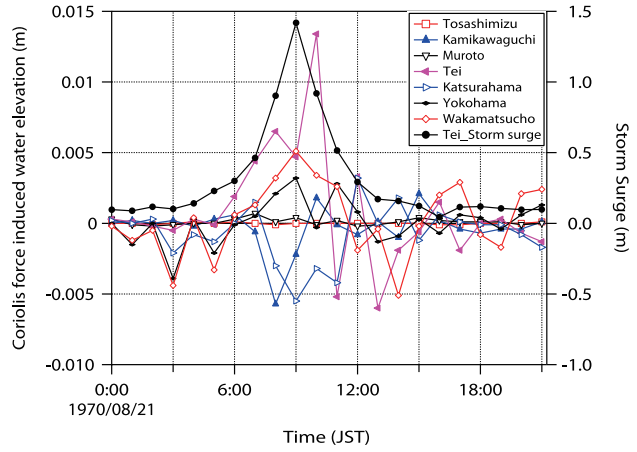

図-11 土佐湾における台風 7010 号の高潮計算結果における Coriolis力の影響

後に発生する最大高潮偏差に及ぼす影響は少ない。

3）山陰沿岸を台風が通過した後に，日本海での風によ る水位変動と流れが，Coriolis力によって向きを変えて 沿岸域へ伝播する現象を再現するには，日本海全域を 含む計算領域を用いる必要がある.

4）土佐湾での高潮計算により，太平洋沿岸域の土佐湾 では高潮偏差に及ぼす Coriolis 力の影響は $1 \%$ と小さか った.

最後に, 本研究は科学研究費補助金若手（スタートア ップ）（20860056）による成果の一部であることをここ に記し，謝意を表する。

\section{参 考 文 献}

金 洙列・間瀬 肇・安田誠宏（2008）：潮汐・高潮・波浪 結合モデルによる土佐湾異常高潮の追算，海岸工学論文 集, 第 55 巻, pp.321-325.

金洙列・松見吉晴 · 安田誠宏 · 間瀬肇 · 河合直樹 （2009）：日本海沿岸における台風通過後の異常高潮特性 の解析, 土木学会論文集 B2 (海岸工学), Vol. B2-65, No. 1, pp.376-380.

柴木秀之・加藤史訓 - 山田浩次（2001）：密度成層とWave Setup 考慮した土佐湾異常高潮の推算, 海岸工学論文集, 第 48 巻, pp.286-290.

Flather, R.A. (1994): A storm surge prediction model for the Northern Bay of Bengal with application to the cyclone disaster in April 1991. J. Phys. Oceanogr. Vol.24, 172?190.

Kim, S. Y., Yasuda, T. and Mase, H. (2008): Numerical Analysis of Effects of Tidal Variations on Storm Surges and Waves, Applied Ocean Research, Vol.30, pp.311-322.

Kim, S. Y., Yasuda, T. and Mase, H. (2010): Wave set-up in the storm surge along open coasts during Typhoon Anita, Coastal Engineering., Vol.57, pp.631-642. 